\section{Disordered eating among Brazilian female college students}

\author{
Comer transtornado entre universitárias brasileiras
}

Comer trastornado entre universitarias brasileñas

\begin{abstract}
${ }^{1}$ Faculdade de Saúde Pública, Universidade de São Paulo, São Paulo, Brasil. 2 Departamento de Ciências da Saúde,Universidade Federal de São Paulo, Santos, Brasil.

Correspondence M. S. Alvarenga Departamento de Nutrição, Faculdade de Saúde Pública Universidade de São Paulo. Av. Dr. Arnaldo 715, São Paulo, SP 01246-904, Brasil. marlealvarenga@gmail.com
\end{abstract}

\section{Abstract}

This study aimed to investigate the socioeconomic and nutritional factors associated with disordered eating among Brazilian female college students $(n=2,489)$. Prevalence ratios of risk factors were calculated using Poisson regression models with robust variance based on responses to selected questions from the Eating Attitude Test and Disordered Eating Attitude Scale. It was found that $40.7 \%$ of students were dieting, $35.6 \%$ were using diet or compensatory methods, $23.9 \%$ skipping meals, $12.6 \%$ not eating or just drinking liquids, and 3.3\%, vomiting to lose weight. A positive association was found between not eating or just drinking liquids and skipping meals and nutritional status after adjustment for age and region. A positive association was found between compensatory methods and dieting and education level of the head of the family. Disordered eating behaviors were frequent, and not eating and skipping meals were more prevalent among overweight/obese students; compensatory methods and dieting were less prevalent among students from families whose head had up to only four years of education. Prevention strategies and food education are necessary in order to decrease the prevalence of these behaviors.

Eating Disorders; Feeding Behavior; Nutritional Status; Socioeconomic Factors
Marle dos Santos Alvarenga ${ }^{1}$ Bárbara Hatzlhoffer Lourenço 1 Sonia Tucunduva Philippi 1 Fernanda Baeza Scagliusi 2

\section{Resumo}

O estudo investigou fatores socioeconômicos e nutricionais associados ao comer transtornado em universitárias brasileiras $(n=2.489)$. Modelos de regressão de Poisson com variância robusta estimaram razões de prevalência de fatores associados ao comer transtornado - avaliado por questões do Teste de Atitudes Alimentares $e$ da Disordered Eating Attitude Scale. Encontrouse que 40,7\% faziam regime para emagrecer; 35,6\% usavam dieta ou métodos compensatórios; $23,9 \%$ pulavam refeições e $12,6 \%$ ficavam à base de líquidos ou sem comer para emagrecer; e 3,3\% vomitavam. Ajustado por idade e região, ficar sem comer ou só com líquidos e pular refeições associaram-se positivamente ao estado nutricional. Compensação e regimes associaram-se positivamente à escolaridade do chefe de família. O comer transtornado foi frequente, sendo que ficar sem comer e pular refeições foram mais prevalentes naquelas com sobrepeso/obesidade; e compensação e regimes menos prevalentes naquelas com chefes de família com menor escolaridade. Estratégias de prevenção e educação alimentar são necessárias para diminuir a frequência destes comportamentos.

Transtornos da Alimentação; Comportamento Alimentar; Estado Nutricional; Fatores Socioeconômicos 


\section{Introduction}

Disordered eating is described as a broad spectrum of eating related problems, including dysfunctional behavior related to dissatisfaction with body shape or size, and inadequate eating behavior, such as purgative practices, binge eating and diet restriction to lose or control weight $1,2,3$.

Partial syndromes of eating disorders and associated risk behavior are well documented 4,5,6 and it is known that the prevalence rate for partial syndromes is at least twice that of complete syndromes. Research highlights that the rate of development of complete eating disorders from partial syndromes varies from $14 \%$ to $46 \% 7$.

Besides the association with classic eating disorders, disordered eating may accelerate weight gain ${ }^{8}$ and generate several psychological and behavioral consequences, such as serious stress, low self-esteem, personality problems and drug and alcohol abuse 8,9.

Disordered eating behaviors are particularly common in young females and are considered "epidemic" among teenagers and college women. The treatment of these debilitating disorders is considered expensive from the health point of view $2,8,9,10$.

Despite this, research on risk behavior related to eating disorders in Brazil is generally limited to sporadic isolated regional studies 11,12 and there is little systematic discussion about the characteristics and frequency of disordered eating among the Brazilian population.

A study that evaluated eating attitudes of Brazilian female college students using the Eating Attitude Test (EAT-26) 6 found a $26.1 \%$ prevalence rate of risk behavior related to eating disorders and a positive correlation between the EAT-26 scores and the Disordered Eating Attitude Scale (DEAS) scores 13 . Considering the high prevalence of risk behavior and the relevance of disordered eating, some of the results of this study are jointly evaluated to analyze specific behaviors from the spectrum of disordered eating, such as dieting and skipping meals. The present study aims to evaluate the presence of such practices and investigate the socioeconomic and nutritional factors associated with selected disordered eating behaviors in a sample of female college students across all Brazilian regions.

\section{Methods}

\section{Study design}

The present study is linked to a project that evaluated eating attitudes among Brazilian female col- lege students. The sample was obtained through a partnership between public and private higher education institutions listed by the National Nutrition Board that were invited to participate by electronic mail. Since no data on disordered eating was available, the sample size was calculated based on a previous study of eating disorder risk among female college students in Brazil 14, resulting in a necessary sample size of 117 subjects per region.

\section{Participants}

A total of 130 institutions were contacted, of which $37(28.5 \%)$ responded and signed a research partnership agreement. For each institution, an average of 80 questionnaires was sent to randomly selected students undertaking undergraduate courses related to health according to the following inclusion criteria: female sex; age > 18 years and $<50$ years, signed informed consent form. Dietitians or students undertaking undergraduate courses in nutrition were excluded because studies have shown that nutrition students have different eating behaviors 14 .

A total of 2,925 questionnaires were sent and 2,547 completed forms were received $(87.1 \%$ response rate) 14 . Response rate by region was: $94.1 \%$ the North (three institutions); $95.7 \%$ for the Northeast (five institutions); $71.1 \%$ for the Central West (five institutions); $85.9 \%$ for the Southeast (12 institutions); and $89 \%$ for the South (12 institutions). Although the Central West Region response rate was particularly low, it was still above the necessary sample size calculated by region. Furthermore, although the amount of institutions in the North and Central West Regions was lower, these numbers are proportional to the number of existing higher education institutions and college students in these regions 14 .

Partially or incorrectly completed forms $(\mathrm{n}=$ 58) were excluded, resulting in a final sample of 2,489 female college students from 37 institutions in the five regions of Brazil.

\section{Measures}

Each institution received specific information about research design and instructions regarding the questionnaires 14 . Specific questions from the DEAS 15 and the EAT-26 16 were evaluated to analyze disordered eating behaviors. Brazilian studies have evaluated risk factors for eating disorders as a whole (using scaled scores), but have rarely addressed the frequency of purgative practices 11,12 . The present study therefore selected questions and statements related to other 
common disordered eating behaviors that have received little research attention.

The DEAS comprises 25 questions that evaluate eating attitudes scored based on the Likert scale. It was developed and validated with Brazilian female college students 15 . The following questions were selected to analyze disordered eating:

- DEAS question 4: "Have you ever spent one or more days without eating or having only liquids because you believed you could lose weight?" (Yes/ No).

- DEAS question 7: “Do you 'skip' meals to avoid putting on weight?" (Yes/No).

- DEAS question 12: "When you eat more than usual, what is your behavior afterwards? (a) restart eating as usual; (b) assume you have lost control and keep eating even more; (c) decide to go on a diet to compensate; (d) use some kind of compensation, such as physical activity, vomiting, laxatives and diuretics".

"Yes" answers to question 4 and 7, and choosing options $\mathrm{C}$ or D as the answer for question 12 were considered positive for disordered eating. The option B to question 12 was not considered DE behavior because it was understood as indulgence, i.e., an "all or nothing" behavior, and not specifically binge eating.

The EAT-26 is a self-administered and comprises 26 questions used to screen eating disorder symptoms. We used the following statements of the validated Portuguese version 16.

- EAT 9: "Vomit after I have eaten".

- EAT 23: "Engage in dieting behavior".

The answer options were: always, usually, often, sometimes, rarely and never. The options with scores different from zero - always, usually, often 16 - were considered positive for disordered eating behavior.

For both the DEAS and EAT, answers were related to the present, since a specific period of time was not described in the explanation of the questions.

Age, self-reported body weight and height were also informed 14; individual per capita income in number of minimum wages (total family income divided by number of people at home), and education level of the head of the family were also informed 14

\section{Statistical analysis}

The general characteristics of the students were described by region, age (both as a continuous variable and according to the following age categories: $\geq 25$ years; 20 to 24 years; $\leq 19$ years), education level of the head of the family (middle or college, elementary, incomplete elementary or illiterate), per capita monthly income in number of minimum wages ( $\geq 2 \mathrm{MW},<2 \mathrm{MW}$ ), and nutritional status according to the body mass index (underweight: $\mathrm{BMI}<18.50 \mathrm{~kg} / \mathrm{m}^{2}$; normal range weight BMI $=18.50-24.99 \mathrm{~kg} / \mathrm{m}^{2}$; overweight or obese BMI $\geq 25 \mathrm{~kg} / \mathrm{m}^{2}$ ). The frequency of positive answers to each question was analyzed by region using Pearson's chi-square.

To investigate socioeconomic factors (education level of the head of the family and per capita income) and nutritional factors (BMI classification) associated with the answers to the questions used to evaluate disordered eating, we used Poisson regression models with robust variance to estimate prevalence ratios (PR). In these models, the disordered eating behavior was the dependent variable, and the independent factor of interest was included, controlling for age and region of Brazil. Controlling for age was deemed necessary because it is a biological characteristic of each participant. The variable region was controlled (using the Central-West as reference) because a previous study suggested the existence of differences in eating habits between the different regions of Brazil 14. Moreover, since socioeconomic factors may affect nutritional status 17 , an additional adjustment for socioeconomic variables was performed to estimate the PR of BMI categories where the education level of the head of the family or the per capita income showed a $\mathrm{p}$-value of $<0.20$. We also analyzed the proportion of positive answers by higher education institutions but no significant association was found. All analyses were conducted using the software Stata 11.2 (Stata Corp., College Station, USA).

Students signed an informed consent form. The study was approved by the Research Ethics Committee of the School of Public Health, São Paulo University (CEP 211/06 - number 1351).

\section{Results}

The general characteristics of the students are shown in Table 1.

Table 2 shows the positive answers to disordered eating questions. The most frequent response $(40.7 \%$ of the total sample) was dieting in order to lose weight $(10.7 \%$ of the total sample answered always to this question, varying between regions from $9.5 \%$ in the Northeast to $12.6 \%$ in the Central-West), followed by using compensatory methods after eating more than usual, skipping meals to avoid putting on weight, and not eating or just drinking liquids to lose weight. Frequency of skipping meals varied among regions $\left(\chi^{2}=11.06 ; p=0.03\right)$, with higher frequency in the North and lower in the South. The least frequent 
Table 1

General characteristics of Brazilian female college students $(N=2,489)$

\begin{tabular}{lcc}
\hline & $\mathbf{n}$ * & $\%$ \\
\hline Region & & \\
Central-West & 199 & 8.0 \\
South & 782 & 31.4 \\
Southeast & 885 & 35.6 \\
$\quad$ Northeast & 383 & 15.4 \\
North & 240 & 9.6 \\
Age (years) & & \\
$\leq 19$ & 685 & 28.3 \\
$20-24$ & 1,054 & 43.4 \\
$\geq 25$ & 685 & 28.3 \\
Mean (SD) & $23.5(6.1)$ & \\
Education level of the head of the family & & 46.6 \\
Middle or college education & 1,113 & 31.4 \\
Elementary education & 749 & 22.0 \\
Incomplete elementary education or illiterate & 526 & \\
Per capita monthly income (number of minimum wages) & & 42.9 \\
$\geq 2$ & 839 & 57.1 \\
$<2$ & 1,119 & \\
Nutritional status & & 9.7 \\
Underweight & 229 & 74.6 \\
Normal body weight & 758 & 15.7 \\
Overweight or obese & 370 & \\
\hline
\end{tabular}

SD: standard deviation.

* The number of participants may differ from 2,489 due to missing information.

Table 2

Frequency (\%) of positive answers to questions evaluating disordered eating among Brazilian female college students $(\mathrm{N}=2,489)$ by region.

\begin{tabular}{lcccccc}
\hline Region & $\mathbf{n}$ & $\begin{array}{c}\text { DEAS 4 } \\
\text { Not eating }\end{array}$ & $\begin{array}{c}\text { DEAS 7 * } \\
\text { Skipping meals }\end{array}$ & $\begin{array}{c}\text { DEAS 12 } \\
\text { Compensatory methods }\end{array}$ & $\begin{array}{c}\text { EAT 9 } \\
\text { Vomiting }\end{array}$ & $\begin{array}{c}\text { EAT 23 } \\
\text { Dieting }\end{array}$ \\
\hline Central-West & 199 & 13.6 & 22.7 & 33.7 & 2.0 & 37.2 \\
South & 782 & 12.2 & 21.1 & 35.5 & 3.5 & 43.1 \\
Southeast & 885 & 11.7 & 23.5 & 35.9 & 3.5 & 40.0 \\
Northeast & 383 & 15.5 & 27.8 & 36.8 & 2.9 & 40.6 \\
North & 240 & 12.5 & 29.6 & 35.6 & 3.8 & 37.8 \\
Total sample & 2,489 & 12.6 & 23.9 & 3.3 & 40.7 \\
\hline
\end{tabular}

DEAS: Disordered Eating Attitude Scale; EAT-26: Eating Attitude Test.

${ }^{*} p=0.03$ for DEAS 7 according to the chi square test; $p>0.40$ for other questions.

behavior was vomiting; in such cases the most frequent answers were often or sometimes and in the South and Southeast regions a small percentage of participants answered always $(0.1 \%$ and $0.5 \%$, respectively).
After adjustment for age and region, it was observed that not eating or just drinking liquids and skipping meals to lose weight were positively and monotonically associated with nutritional status, but not with socioeconomic character- 
istics (Table 3). The practice of these behaviors as a weight control strategy was approximately $50 \%$ more prevalent in overweight or obese students than students with normal body weight $(\mathrm{p}<0.01)$.

Using compensatory methods after eating more than usual and dieting were positively associated with the education level of the head of the family. The lower the education level, the lower the PR for positive answers to these questions. Where the head of the family was illiterate or had not completed elementary school the prevalence of these behaviors was lower (15\% and $13 \%$, respectively) compared to those whose head of the family had middle level education or attended college, regardless of age or region ( $p$ $=0.04$ ). Furthermore, a positive association was found between these two questions and nutritional status after adjustment for age, region and education level of the head of the family (Table 3 , model 2).

The use of compensatory methods was $71 \%$ less prevalent among underweight students and $44 \%$ more prevalent among overweight/obese students than in students with normal body weight $(\mathrm{p}<0.0001)$. In addition, dieting to lose weight was $78 \%$ less prevalent in underweight students and $83 \%$ more prevalent in overweight/ obese students than in students with normal body weight $(\mathrm{p}<0.0001)$.

No association was found between vomiting and socioeconomic characteristics and nutritional status.

\section{Discussion}

The present study of disordered eating behaviors among Brazilian female college students observed that all the evaluated behaviors were frequent across all regions, with the exception of vomiting; dieting in order to lose weight and the use of compensatory methods after eating more than usual were particularly common practices.

Other studies have found that $64 \%$ of the female college population had some type of disordered eating habit. It is important to note however that it is difficult to estimate prevalence due to a lack of universal evaluation criteria ${ }^{18}$. It is important to note that the evaluation of the specific question regarding diet practice by the present study showed much higher prevalence $(40.7 \%)$ than overall risk behavior (26.1\%) assessed by the previous study of the same group which considered the scaled score of all EAT-26 responses, emphasizing the importance of specific behavior evaluation. Furthermore, based on all positive answers to the behavior questions evaluated by the present study, $56.2 \%$ of the sample had some type of disordered eating habit, showing that the results of this study are similar to the findings of other studies carried out elsewhere.

In this first evaluation in the Brazilian context, specific socioeconomic and nutritional factors (per capita income and education level of the head of the family and BMI) associated with disordered eating were explored. It is proposed that future studies should assess other associated factors, such as thin ideal internalization, body dissatisfaction, sociocultural influences and stress.

\section{Frequency of disordered eating behaviors}

\section{- Vomiting}

The prevalence of vomiting was low and no association was found between this practice and the proposed risk factors. This habit is the most serious of the disordered eating behaviors evaluated by this study and has dangerous implications 19 and to date few studies in Brazil have explored this purging behavior separately. Therefore, we believe that even such a relatively low prevalence is still cause for alarm and it is recommended that this behavior should be a focus for prevention initiatives.

Widespread research on disordered eating among adolescents 4,10 shows that between 5 and $15 \%$ of girls adopt purging practices (vomiting or use of diuretics or laxatives). In Brazil, a study that evaluated specific compensatory methods in a probabilistic sample of 561 adolescents from public schools in Rio de Janeiro found that $1.4 \%$ admitted to vomiting every week, $2.1 \%$, to used laxatives and $1.6 \%$ used diuretics 11 . Another study that evaluated the same practices among 1,524 randomly selected women aged between 12 and 29 years in the Southern Region of Brazil showed that $8.5 \%$ used laxatives, $3.1 \%$ fasted, $2.8 \%$ used diuretics and $1.4 \%$ vomited 12 .

The prevalence of vomiting observed by the present study is higher than the findings of the above studies and this result requires further investigation.

\section{- Not eating or just drinking liquids and skipping meals}

Skipping meals and not eating or just drinking liquids were the third and fourth most commonly used weight loss "strategies". It can be observed therefore that these scientifically questionable and potentially harmful methods are popular even among a theoretically more informed group of people. Biener \& Heaton 20 found that dieting women were generally younger, had more years 
Factors associated with positive answers to the questions evaluating disordered eating among Brazilian female college students $(\mathrm{N}=2,489)$.

\begin{tabular}{|c|c|c|c|c|}
\hline & \multicolumn{2}{|c|}{ Model 1 * } & \multicolumn{2}{|c|}{ Model 2 ** } \\
\hline & PR (SE) & $95 \% \mathrm{Cl}$ & PR (SE) & $95 \% \mathrm{Cl}$ \\
\hline \multicolumn{5}{|l|}{ DEAS 4 - Not eating or just taking liquids } \\
\hline Level of education of the head of the family & & - & - & - \\
\hline Middle or College & 1.00 & - & - & - \\
\hline Elementary & $0.97(0.13)$ & $0.75-1.25$ & - & - \\
\hline Incomplete elementary or illiterate & $1.15(0.16)$ & $0.88-1.50$ & - & - \\
\hline \multicolumn{5}{|c|}{ Per capita monthly income (number of minimum wages) } \\
\hline$\geq 2$ & 1.00 & - & - & - \\
\hline$<2$ & $0.95(0.12)$ & $0.75-1.21$ & - & - \\
\hline \multicolumn{5}{|l|}{ Nutritional status } \\
\hline Underweight & $0.64(0.15)$ & $0.41-1.01$ & - & - \\
\hline Normal range weight & 1.00 & - & - & - \\
\hline Overweight or obesity & $1.53(0.21)$ & $1.80-2.00$ & - & - \\
\hline \multicolumn{5}{|l|}{ DEAS 7 - Skipping meals } \\
\hline \multicolumn{5}{|l|}{ Education of the family head } \\
\hline Middle or College & 1.00 & - & - & - \\
\hline Elementary & $1.06(0.09)$ & $0.90-1.25$ & - & - \\
\hline Incomplete elementary or illiterate & $1.01(0.10)$ & $0.83-1.22$ & - & - \\
\hline \multicolumn{5}{|l|}{ Per capita monthly income (minimum wages) } \\
\hline$\geq 2$ & 1.00 & - & - & - \\
\hline$<2$ & $1.07(0.09)$ & $0.91-1.25$ & - & - \\
\hline \multicolumn{5}{|l|}{ Nutritional status } \\
\hline Underweight & $0.40(0.08)$ & $0.27-0.61$ & - & - \\
\hline Normal range weight & 1.00 & - & - & - \\
\hline Overweight or obesity & $1.56(0.13)$ & $1.32-1.84$ & - & - \\
\hline \multicolumn{5}{|c|}{ DEAS 12 - Compensatory methods after eating more than usual } \\
\hline \multicolumn{5}{|l|}{ Education of the family head } \\
\hline Middle or College & 1.00 & - & - & - \\
\hline Elementary & $0.94(0.06)$ & 0.83-1.07 & - & - \\
\hline Incomplete elementary or illiterate & $0.85(0.06)$ & $0.73-0.99$ & - & - \\
\hline \multicolumn{5}{|l|}{ Per capita monthly income (minimum wages) } \\
\hline$\geq 2$ & 1.00 & - & - & - \\
\hline$<2$ & $0.96(0.06)$ & $0.85-1.09$ & - & - \\
\hline \multicolumn{5}{|l|}{ Nutritional status } \\
\hline Underweight & $0.30(0.06)$ & $0.21-0.44$ & $0.29(0.06)$ & $0.20-0.43$ \\
\hline Normal range weight & 1.00 & - & 1.00 & - \\
\hline Overweight or obesity & $1.44(0.09)$ & $1.27-1.63$ & $1.44(0.09)$ & $1.27-1.63$ \\
\hline \multicolumn{5}{|l|}{ EAT 23 - To diet to lose weight } \\
\hline \multicolumn{5}{|l|}{ Education of the family head } \\
\hline Middle or College & 1.00 & - & - & - \\
\hline Elementary & $0.91(0.05)$ & $0.81-1.02$ & - & - \\
\hline Incomplete elementary or illiterate & $0.87(0.06)$ & $0.76-0.99$ & - & - \\
\hline \multicolumn{5}{|l|}{ Per capita monthly income (minimum wages) } \\
\hline$\geq 2$ & 1.00 & - & - & - \\
\hline$<2$ & $0.95(0.05)$ & $0.85-1.06$ & - & - \\
\hline \multicolumn{5}{|l|}{ Nutritional status } \\
\hline Underweight & $0.24(0.05)$ & $0.16-0.36$ & $0.22(0.05)$ & $0.14-0.34$ \\
\hline Normal body weight & 1.00 & - & 1.00 & - \\
\hline Overweight or obese & $1.83(0.09)$ & 1.67-2.01 & $1.83(0.09)$ & 1.67-2.02 \\
\hline
\end{tabular}

PR: prevalence ratio; SE: standard error; $95 \% \mathrm{Cl}$ : $95 \%$ confidence interval.

* Model 1: adjusted by age and region.

** Model 2: model $1+$ education level of the head of the family.

Note: PR (SE) was obtained using Poisson regression models with robust variance. Socioeconomic variables were retained in the analysis for additional adjustment of the association between disordered eating and nutritional status when $p<0.20$. 
of study and perceived themselves as healthy, even though 12 to $27 \%$ used dangerous or questionable weight loss strategies (24-hour fasting, laxatives, diuretics, pills, vomiting, hormones and supplements). It is assumed that there is a general lack of awareness of the fact that food restriction and irregular eating do not lead to long term weight loss or that these practices may decrease energy expenditure and are therefore potentially counter productive 8,21,22,23,24,25,26,27,28.

\section{- Dieting}

Dieting was the most frequent disordered eating behavior analyzed, and it is known that especially young women diet in some moment of their lives 2,25,26,28. Comparisons of this study's findings with other studies in Brazil are limited since studies that separately analyze specific disordered eating behaviors are sporadic. Studies conducted in the USA show that the frequency of dieting among adult women with normal body weight is between $29 \%$ and $38 \% 20$. Considering that the majority of the present sample had an normal body weight, the prevalence of dieting could be considered somewhat higher than that found by the American study.

It should be emphasized that current knowledge of nutrition and weight regulation confirms that dieting is fruitless and leads to weight regain, a decrease in metabolic rates and has physical and psychological consequences 8,21,22,25,26,28. Longitudinal studies have shown that dieting could be a predictor of future disordered eating, weight gain and obesity 29,30,31.

Furthermore, in people with normal body weight, dieting has been associated with stress, mood changes, lower self esteem, and cognitive effects 20. Longitudinal studies have also observed that $35 \%$ of individuals on less strict diet regimes became "pathological" dieters and that 20 to $30 \%$ of pathological dieters developed partial or complete eating disorder syndromes 5 .

\section{- Using compensatory methods after eating more than usual}

It is not possible to differentiate between the methods listed in the DEAS question 12 (dieting to physical activities, vomiting, laxatives and diuretics) because participants did not specify the compensation method used. We were unable to compare the results of this part of the analysis due to the lack of studies evaluating compensatory methods. However, the results highlight the flaws in the idea of such methods whose logic consists of treating food intake as "calorie credits", diverting focus from diet quality and contrib- uting to the development of dysfunctional eating habits 21,28 .

The fact that dieting was the most common practice among the sample may suggest that this strategy is also the most commonly used compensatory method; however, further investigation is required to confirm this possibility. Also, given that vomiting had the lowest prevalence, it is reasonable to assume that the compensatory methods used are spread across physical activity, laxatives and diuretics.

If the results of the present study were comparable with the two Brazilian studies mentioned above, the prevalence of laxative and diuretics use would be around 2 to $8.5 \%$ and 1.5 to $3 \%$, respectively 11,12 . A computerized estimate (excluding diet, vomiting, laxatives and diuretics) suggests that the prevalence of physical activity as a compensatory method is around $50 \%$. Physical activity is generally considered "healthy" and is rarely seen as compulsive, excessive or inadequate. However, it is sometimes used as compensatory method associated with eating disorders and may have psychological and physiological consequences 32 .

\section{Associations with nutritional status and education level of the head of the family}

The prevalence of positive answers for all questions was higher in overweight and obese students. Nunes et al. 12 also found that "abnormal" eating patterns were more prevalent among overweight and obese women in the Southern Region of Brazil. A simplistic conclusion is that given that these people are overweight they are more likely to experiment weight loss strategies. It is important to note that the other "less severe" behaviors evaluated by the present study, apart from vomiting or the use of laxatives and diuretics, are also ineffective and have dangerous health consequences $21,22,28$.

Women who are anxious about their weight are more likely to develop eating disorders 7 and, considering the sociocultural pressure in Brazil, it is reasonable to assume that the overweight students in the present study fall into this group. Overweight students have higher levels of body dissatisfaction and are stigmatized by current culture that proposes unattainable body and beauty ideals. Body dissatisfaction is a potential risk factor for disordered eating and the development of complete eating disorder syndromes and is associated with long-term weight gain 8 . Prevention and health promotion strategies should therefore focus on healthy eating and exercise instead of dieting and compensatory methods. 
The variables skipping meals, not eating or just drinking liquids were associated with nutritional status and were more prevalent in overweight and obese students. On the other hand, compensatory methods and dieting were directly related to the education level of the head of the family and student's nutritional status. It could therefore be concluded that more "immediate" behaviors (skipping meals, not eating) are associated to current nutritional status, whereas behaviors that depend on internalized concepts, such as the appeal of compensatory methods or dieting, are also influenced by socioeconomic status. With respect to the latter factors, prevalence of these practices was lower in students from families where the education level of the head of the family was lower; no difference was found between intermediate or higher levels of education. We were unable to compare these results due to the lack of similar studies in the literature.

With regard to socioeconomic factors, no association was found between per capita income and disordered eating. However, prevalence of dieting and compensatory methods was lower in students from families where the education level of the head of the family was lower. Although it is appears that sociocultural pressure with respect to the ideal body and eating reaches all social classes due to the mass media and global homogenization of beauty ideals, this result suggests a difference in behavior between more and less privileged classes. A study by Sischo et al. ${ }^{2}$ found no association between socioeconomic status and the prevalence of disordered eating practices, but found that increased income was associated with increased weight worries and dieting among American women 33. However, it is important to note that differences may exist between developed and emerging countries and there is a lack of studies on disordered eating in Brazil to compare results and corroborate such findings.

\section{Limitations}

To the best of our knowledge, this was the first study to evaluate disordered eating behaviors using this terminology in Brazil. The lack of a common definition and universal standards for analyzing disordered eating means that the behaviors evaluated by this study and the questions used are susceptible to criticism.

Although this study used questions from instruments with recognized validity and reliability 15,16 that are applicable to larger samples, due to the lack of standards for measuring disordered eating behaviors, it is probable that the question format did not provide a sufficient insight into daily dieting and disordered eating habits. Even more, to ask about diet practice is extremely broad and could encompass distinct eating behaviors. Thus, it is necessary to understand what people mean when they answer that they are dieting.

With regard to the findings on nutritional status, it should be noted that weight and height were self-reported. However, a meta-analysis 34 concluded that self-reported height and weight are good estimates of actual measures, a high level of consistency has been found between self-reported and measured data in Brazil, and self-reported data are considered reliable when actual measures are not available for epidemiological studies 35,36 .

\section{Applicability of presented results}

Eating and weight problems are extremely worrying in the present context. It is necessary to evaluate the whole spectrum of eating disorders, not just overweight, obesity and the classic eating disorders. Etiological factors must be identified before they are made indistinct by physical and psychological changes which accompany obesity and eating disorders 24 .

The association between overweight and disordered eating suggests that combined interventions could have positive synergic effects 8 . Obesity and disordered eating share common characteristics and risk factors, such as body dissatisfaction, low self-esteem, dieting, binging, the influence of the media, weight teasing and extreme worry about body weight.

Current public health strategies that focus on obesity could exacerbate the disordered eating problem ${ }^{8}$. Health professionals should focus their attention on treating patients with disordered eating behaviors using counseling techniques to normalize eating and reduce dysfunctional thoughts and practices. Public health authorities should transmit messages about the health risks involved in dieting practices in order to raise awareness about the flaws of these and other popular body weight control practices, and draw attention to the benefits of a healthy lifestyle 22,25,27.

\section{Conclusion}

Disordered eatingbehaviorswerefrequentamong this sample of Brazilian female college students, especially dieting, using compensatory methods after eating more than usual and skipping meals. Not eating and skipping meals were positively associated with nutritional status, and were more 
prevalent among overweight and obese students. Compensatory methods and dieting were positively associated with the education level of the head of the family, with lower prevalence among participants whose head of the family had up to only four years of education.

Further studies of disordered eating behaviors and all associated risk factors across dif- ferent groups in Brazil are recommended. The knowledge generated by such studies will serve to orientate eating education programs whose focus goes beyond the food and nutrient intake approach, and joint obesity and eating disorders prevention programs.

\section{Resumen}

El estudio investigó factores socioeconómicos y nutricionales asociados a la alteración del orden de las comidas en universitarias brasileñas $(n=2.489)$. Modelos de regresión de Poisson con variancia robusta estimaron razones de prevalencia de factores asociados a comer trastornado -evaluado por preguntas del Test de Actitudes Alimentarias y la Disordered Eating Attitude Scale. Se halló que un 40,7\% hacían régimen para adelgazar; un $35,6 \%$ seguían una dieta o métodos compensatorios; un $23,9 \%$ se saltaban comidas y un $12,6 \%$ comian a base de líquidos o se quedaban sin comer para adelgazar; $y$ un 3,3\% vomitaban. Ajustado por edad y región, quedarse sin comer o sólo con líquidos y saltarse comidas se asoció positivamente con el estado nutricional. Compensación y régimen se asociaron positivamente con la escolaridad del jefe de familia. Comer trastornado fue frecuente, siendo que quedarse sin comer y saltarse comidas fueron más prevalentes en aquellas con sobrepeso/obesidad; y compensación y régimen menos prevalentes en aquellas con jefes de familia con menor escolaridad. Las estrategias de prevención y educación alimentaria son necesarias para disminuir la frecuencia de estos comportamientos.

Trastornos de la Conducta Alimentaria; Conducta Alimentaria; Estado Nutricional; Factores Socioeconómicos

\section{Contributors}

M. S. Alvarenga was responsible for study conception and design, data analysis and interpretation, and drafting and final revision of this article after the contributions of the coauthors. B. H. Lourenço and F. B. Scagliusi collaborated with statistical analysis, data analysis and interpretation, critical revision of the intellectual content and approval of the final version of this article. S. T. Philippi contributed to study conception and interpretation of data and to the revision and approval of the final version of this article.

\section{Acknowledgments}

The authors would like to thank the nutrition course coordinators of the participant institutions for their significant contribution to data collection. We are also grateful to FAPESP (06/56850-9) for the financial support.

\section{References}

1. American Dietetic Association (ADA). Position of the American Dietetic Association: nutrition intervention in the treatment of anorexia nervosa, bulimia nervosa, and other eating disorders. J Am Diet Assoc 2006; 106:2073-82.

2. Sischo L, Taylor J, Martin PY. Carrying the weight of self-derogation? Disordered eating practices as social deviance in young adults. Deviant Behav 2006; 27:1-30.

3. Kelly SD, Howe CJ, Hendler JP, Lipman TH. Disordered eating behaviors in youth with type 1 diabetes. Diabetes Educ 2005; 34:572-83.

4. Hautala L, Helenius H, Karukivi M, Maunula AM, Nieminen J, Aromaa M, et al. The role of gender, affectivity and parenting in the course of disordered eating: a 4-year prospective case-control study among adolescents. Int J Nurs Stud 2011; 48:959-72.

5. Shisslak CM, Crago MA. Does dieting lead to weight gain? A four-year longitudinal study of middle school girls. Obesity 2006; 14:2236-41.

6. Alvarenga MS, Scagliusi FB, Philippi ST. Comportamento de risco para transtorno alimentar em universitárias brasileiras. Rev Psiquiatr Clín 2011; 38:3-7.

7. Shisslak CM, Crago M, Estes LS. The spectrum of eating disturbances. Int J Eat Disord 1995; 18: 209-19.

8. Urquhart CS, Mihalynuk TV. Disordered eating in women: implications for the obesity pandemic. Can J Diet Pract Res 2011; 72:e115-25.

9. Wright A, Pritchard ME. An examination of the relation of gender, mass media influence, and loneliness to disordered eating among college students. Eat Weight Disord 2009; 14:e144-7.

10. Neumark-Sztainer D, Wall MM, Haines JI, Story MT, Sherwood NE, van den Berg PA. Shared risk and protective factors for overweight and disordered eating in adolescents. Am J Prev Med 2007; 33:359-69.

11. Ferreira JES, Veiga GV. Eating disorders risk behavior in Brazilian adolescents from low socio-economic level. Appetite 2008; 51:249-55.

12. Nunes MA, Barros FC, Olinto MTA, Camey S, Mari JDJ. Prevalence of abnormal eating behaviors and inappropriate methods for weight control in young women from Brazil: a population-based study. Eat Weight Disord 2003; 8:100-6. 
13. Alvarenga MS, Scagliusi FB, Philippi ST. Eating attitudes of female Brazilian university students with eating disorder risk behavior. Journal of Behavior Health \& Social Issues 2010; 2:47-54.

14. Alvarenga MS, Scagliusi FB, Philippi ST. Comparison of eating attitudes among university students from the five Brazilian regions. Ciênc Saúde Coletiva $2012 ; 17: 435-44$.

15. Alvarenga MS, Scagliusi FB, Philippi ST. Development and validity of the Disordered Eating Attitude Scale (DEAS). Percept Mot Skills 2010; 111:379-95.

16. Bighetti F, Santos CB, Santos JE, Ribeiro RPP. Tradução e validação do Eating Attitudes Test em adolescentes do sexo feminino de Ribeirão Preto-SP. Bras Psiquiatr 2004; 53:339-46.

17. Monteiro CA, Conde WL, Popkin BM. Income-specific trends in obesity in Brazil: 1975-2003. Am Public Health 2007; 97:1808-12.

18. Boyce T. Media, moral panics and obesity. Sociol Rev 2009; 18:30-2.

19. Polacow VO, Alvarenga MS. Complicações clínicas nos transtornos alimentares. In: Alvarenga MS Scagliusi FB, Philippi ST, organizadores. Nutrição e transtornos alimentares - avaliação e tratamento. Barueri: Editora Manole; 2011. p. 173-96.

20. Biener L, Heaton A. Women dieters of normal weight: their motives, goals and risks. Am J Public Health 1995; 85:714-7.

21. Chaput JP, Doucet E, Tremblay A. Obesity: a disease or a biological adaptation? An update. Obes Rev 2012; 13:681-91.

22. Wooley CS, Garner DM. Controversies in management: dietary treatments for obesity are ineffec tive. BMJ 1994; 309:655-6.

23. Anderson JW, Konz EC, Frederich RC, Wood CL. Long-term weight-loss maintenance: a meta-analysis of U.S. studies. Am J Clin Nutr 2001; 74:579-84

24. Ferrier AG, Martens MP. Perceived incompetence and disordered eating among college students. Eat Behav 2008; 9:111-9.
25. Polivy J. Psychological consequences of food re striction. J Am Diet Assoc 1996; 96:589-92.

26. Freedman MR, King J, Kennedy E. Popular diets: a scientific review. Obes Res 2001; 9 Suppl 1:1S-40S.

27. Puhl RM, Heuer CA. Obesity stigma: important considerations for public health. Am J Public Health 2010; 100:1019-25.

28. Polivy J, Herman CP. An evolutionary perspective on dieting. Appetite 2006; 47:30-5.

29. Lowe MR, Annunziato RA, Markowitz JT, Didie E, Bellace DL, Riddell L, et al. Multiple types of dieting prospectively predict weight gain during the freshman year of college. Appetite 2006; 47:83-90.

30. Neumark-Sztainer D, Wall M, Story M, Haines J, Eisenberg M. Obesity, disordered eating and eating disorders in a longitudinal study of adolescents: how do dieters fare 5 years later? J Am Diet Assoc 2006; 106:559-68.

31. Patton GC, Selzer R, Coffey C, Carlin JB, Wolfe R. Onset of adolescent eating disorders: popula tion based cohort study over 3 years. BMJ 1999; 318:765-8.

32. Teixeira PC, Costa RF, Matsudo SM, Cordás TA A prática de exercícios físicos em pacientes com transtornos alimentares. Rev Psiquiatr Clín 2009; 36:145-52.

33. Jeffery RW, French SA. Socioeconomic status and weight control practices among 20- to 45-year-old women. Am J Public Health 1996; 86:1005-10.

34. Bowman R, De Lucia J. Accuracy of self-reported weight: a meta-analysis. Behav Ther 1992; 23 637-55.

35. Fonseca MJM, Faerstein E, Chor D, Lopes CS. Validade de peso e estatura informados e índice de massa corporal: estudo pró-saúde. Rev Saúde Pública 2004; 38:392-8.

36. Peixoto MRG, Benício MHD, Veiga PCB. Validade do peso e da altura auto-referidos: o estudo de Goiânia. Rev Saúde Pública 2006; 40:1065-72.

Sumitted on $26 / \mathrm{Jul} / 2012$

Final version resubmitted on $01 / \mathrm{Dec} / 2012$

Approved on 10/Jan/2013 